\title{
PENGARUH PENGEMBANGAN KARIR DAN MOTIVASI KERJA TERHADAP KINERJA KARYAWAN PADA PURI LUMBUNG COTTAGES RESTAURANT AND SPA MUNDUK
}

\author{
Putu Eko Wahyudi ${ }^{1}$, Komang Krisna Heryanda², Gede Putu Agus Jana Susila ${ }^{2}$ \\ 1,2,3Universitas Pendidikan Ganesha, Singaraja \\ e-mail: pt.ekowahyudi@gmail.com¹, krisna.heryanda@undiksha.ac.id², \\ agus.jana@undiksha.ac.id ${ }^{3}$
}

\begin{abstract}
Abstrak
Penelitian ini bertujuan untuk menguji pengaruh: (1) pengembangan karir dan motivasi kerja terhadap kinerja karyawan, (2) pengembangan karir terhadap kinerja karyawan, (3) motivasi kerja kerja terhadap kinerja karyawan dan (4) pengembangan karir terhadap motivasi kerja pada Puri Lumbung Cottages Restaurant and Spa Munduk. Desain penelitian yang digunakan dalam penelitian ini adalah kuantitatif kausal. Objek penelitian ini adalah pengembangan karir, motivasi kerja dan kinerja karyawan. Subjek penelitian adalah seluruh karyawan Puri Lumbung Cottages Restaurant and Spa Munduk dengan jumlah populasi sebanyak 87 orang. Data yang dikumpulkan dengan metode wawancara dan kuesioner. Teknik analisis yang digunakan adalah analisis jalur. Hasil penelitian menunjukkan bahwa: (1) pengembangan karir dan motivasi kerja berpengaruh positif dan signifikan terhadap kinerja karyawan (2) pengembangan karir berpengaruh positif dan signifikan terhadap kinerja karyawan, (3) motivasi kerja berpengaruh positif dan signifikan terhadap kinerja karyawan dan (4) pengembangan karir berpengaruh positif dan signifikan terhadap motivasi kerja pada Puri Lumbung Cottages Restaurant and Spa Munduk.
\end{abstract}

Kata kunci: pengembangan karir, motivasi kerja, kinerja karyawan

\section{Abstract}

This study aims to examine the effects of: (1) career development and motivation on employee performance, (2) career development on employee performance, (3) motivation on employee performance and (4) career development on motivation at Puri Lumbung Cottages Restaurant and Spa Munduk. The research design used in this research is causal quantitative. The object of this research is career development, motivation and employee performance. The research subjects were all employees of Puri Lumbung Cottages Restaurant and Spa Munduk with a population of 87 people. Data collected by interview and questionnaire methods. The analysis technique used is path analysis. The results showed that: (1) career development and motivation have positive and significant effect on employee performance (2) career development has a positive and significant effect on employee performance, (3) motivation has a positive and significant effect on employee performance and (4) development career has a positive and significant effect on work motivation at Puri Lumbung Cottages Restaurant and Spa Munduk.

Keywords: career development, motivation and employee performance 


\section{PENDAHULUAN}

Industri pariwisata memiliki peranan sangat penting dalam pertumbuhan ekonomi Indonesia. Peran tersebut adalah menciptakan lapangan kerja bagi masyarakat (Soebagyo, 2012). Pariwisata dapat diartika sebagai salah satu industri gaya baru yang menyediakan pertumbuhan ekonomi yang sangat cepat dalam hal kesempatan kerja,pendapatan, taraf hidup, dan dalam mengatifkan sektor produksi di dalam Negara penerima wisatawan. Perkemangan pariwisata sangat berkembang dengan sangat pesat pada jasa penyedian akomodasi. Hal tersebut dikarenakan pembenahan fasilitas pariwisata yang terus meningkat penyedian jasa akomodasi pariwisata untuk mencapai tempat tinggal sementara selama berada di daerah tertentu.

Hotel merupakan salah satu penyedian akomodasi yang paling sering digunakan oleh pariwisata. Kemudahan akses untuk menginap dan fasilitas yang sangat bagus ataupun pelayanan di hotel menjadikan sebagai pilihan yang tepat bagi wisatawan mendapatkan kenyamanan. Pertumbuhan hotel yang sangat pesat meningkatkan persaingan yang kompetitif khususnya di daerah bali utara. Daerah ini memiliki beragam objek seperti air terjun, danau,wisata alam. Salah satu kawasan wisata yang terkenal adalah Desa Munduk, yang memiliki tingkat kunjunagan wisatawan mencapai 61.738 jiwa karena keindahan alam yang mempesona. Hal tersebut sejalan dengan bertambahnya hotel dari tahun ke tahun. Khusus daerah kabupaten Buleleng, jumlah hotel mencapai 10 hotel berbintang, 58 hotel melati dan 2.180 jumlah total kamar keseluruhan pada tahun 2019 (Dinas pariwisata Kabupaten Buleleng). Meningkatnya pertumbuhan ekonomi khususnya di daerah Desa Munduk menumbuhkan daya saing bagi wisatawan.

Salah satu hotel yang ikut bersaing adalah Hotel puri lumbung cottages Restaurant and Spa munduk. Hotel ini merupakan hotel berbintang yang menawarkan berbagai macam fasilitas kamar. Hotel puri lumbung memiliki pemandangan alam yang dapat dinikmati langsung oleh wisatawan. Pada awal berdiri tahun 1992. Hotel ini sangat dinikmati oleh wisatawan sehingga puri lumbung cottages Restaurant and Spa Munduk mendapatkan keuntungan dan penjualan kamar mengalami penurunan penjualan dilihat dari penjualan kamar yang terus menurun dibandingakan hotel berbintang lainya di daerah buleleng. Hal ini dapat diketahui pada pada tabel 1.

Tabel 1.

Data pembanding Penjualan Kamar Hotel Per periode Oktober-Desember 2019

\begin{tabular}{clccc}
\hline \multirow{2}{*}{ No } & \multicolumn{1}{c}{ Nama Hotel } & \multicolumn{3}{c}{ Tingkat Penjualan Per Bulan } \\
\cline { 3 - 5 } & & Oktober & November & Desember \\
\hline \multirow{2}{*}{1} & $\begin{array}{l}\text { Puri Lumbung Cotaages } \\
\text { Restaurant and Spa Munduk }\end{array}$ & 102 & 54 & 47 \\
\hline 2 & Hotel Puri Saron Lovina & 56 & 137 & 182 \\
\hline 3 & Munduk Moding Plantation & 743 & 620 & 627 \\
\hline
\end{tabular}

Pada Tabel 1. menunjukkan tingkat penjualan kamar di Puri lumbung Cotaages Restaurant and Spa Munduk periode oktober-Desember 2019 berada pada posisi terendah dimana tingkat penjualan kamar terus mengalami penurunan. Pada bulan oktober jumlah penjualan kamar Puri lumbung Cotaages Restaurant and Spa Muduk mengalami penurunan sebesar $47 \%$ di bulan 
november dan pada bulan Desember mengalami penurunan sebesar $12 \%$. Sedangkan pada hotel lainya memiliki tingkat penjualan kamar yang meningkat setiap bulan.

Hasibuan (2001) mengemukakan kinerja adalah suatu hasil kerja yang dicapai seseorang dalam melaksanakan tugas yang dibebankan kepadanya yang di dasarkan atas kecakapan, pengalaman pengalaman dan kesungguhan waktu. Apabila karyawan memaksimalkan kinerja dalam perusahaan maka karyawan maupun pihak lainya mendapatkan manfaat dari pengoptimalan kinerja, oleh karna itu pihak hotel selaku usaha sangat perlu untuk meningkatkan kinerja karyawan dan mengembangkan kemampuan dalam kinerja karyawan.untuk megetahui seberapa besar tingakt kinerja karyawan pada puri lumbung cottages Restaurant and Spa munduk dapat dilihat dari beberapa indikator diantaranya jumlah pekerjaan dari kariyawan, kuantitas karyawan itu dalam menyelesaian suatu pekerjan dengan cepat atau lambat, kemampuan karyawan mengerjak tugas dengan akurat tampa kesalahan dan tanggung jawab dari karyawan itu sendiri dalam menyelesaikan pekerjaan. Dalam hal ini dapat dijabarkan masingmasing indikator tersebut diantaranya kualitas kerja karyawan Puri Lmbung Cottages Restaurant and Spa munduk yang masih tergolong rendah karena dalam pembanding pejualan kamar masih rendah tidak sesuai dengan penjualan kamar dari karyawan di hotel masih kurang sehingga karyawan dalam bekerja tidak dapat menunjukan kualitas secara optimal.begitu pula dengan kuantitas kerja yang dilakukan karyawan belum efektif dan efisien karena masih mempelajari pekerjaan yang diberikan dari pihak hotel dengan demikian membuat pekerjaan sedikit lambat. Sedangkan indikator kerjasama karyawan masih adanya kesalahan-kesalahan yang dilakukan oleh karyawan yaitu kerjasama dari karyawan hotel masih kurang dalam melakukan suatu pekerjaan dan mempersulit pencapaian kinerja secara optimal. Dimana wisatawan yang berkunjung melihat kinerja karyawan di hotel melihat karyawan masih kurang dalam melakukan kerja sama. Kemudian kewajiban dalam bekerja yang dilakukan dengan penuh tanggung jawab belum demikian karyawan secara keseluruhan karena dalam pencapaian penjualan kamar tidak mampu dicapai oleh karyawan itu sendiri. Perlu dilakukan penelitian awal, hal ini dilakukan dengan menyebarkan kuesioner awal kepada 10 responden karyawan terdapat lima indikator di antaranya: $\left(Y_{1}\right)$ jumlah pekerjaan, $\left(Y_{2}\right)$ Kualitas pekerjaan, $\left(Y_{3}\right)$ kreaktifitas, $\left(Y_{4}\right)$ kerjasama, $\left(Y_{5}\right)$ loyalitas kerja.beikut merupakan tabel dari hasil kuisioner kinerja karyawan. Hasil observasi awal variabel kinerja karyawan menunjukkan penilaian mengenai kinerja karyawan di Puri Lumbung Cottages Restaurant and Spa Munduk masih tergolong rendah. Indikator jumlah pekerjaan dan kejar sama memiliki pengaruh yang besar terhaap kinerja karyawan. Rendahnya kinerja karyawan diduga disebabkan oleh pengembangan karir dan motivasi krja dilihat dari karyawan hotel yang menawarkan harga penjualan kamar yang lebih sesuai dengan manfaat yang diterima.Hal ini sejalan dengan pendapat Wibowo (2007) bahwa karyawan mempunyai kesempatan yan tinggi meningkatkan karirnya akan merangsang motivasinya untuk bekerja lebih baik. Bedasarkan permasalahan tersebut di duga bahwa ketidak capian kinerja karyawan disebabkan karena beberpa faktor diantaranya pengembangan karir dan motivasi kerja.

Menurut Martoyo (2007) pengembangan karir adalah suatu kondisi yang menunjukkan adanya peningkatan-peningkatan status seseorang dalam suatu organisasi dalam jalur karir yang telah ditetapkan dalam organisasi yang bersangkutan. Sementara itu, Gorda (2004; 149) menyatakan bahwa pengembangan karir dalam suatu perusahaan akan semakin meningkatkan kepuasan karyawan, loyalitas dan kratifitas, kondisi yang demikian akan merupakan faktor pendorong peningkatan kinerja karyawan. Dalam setiap pekerjaan, karyawan membutuhkan adanya pengembangan karir guna menunjang semangat kerja untuk memberikan pelayanan yang terbaik. Apabila pihak perusahaan mengabaikan hal tersebut, karyawan tidak memiliki daya saing yang kuat dan mengurangi kepuasan kerja dalam sebuah perusahaan, hal tersebut tentunya berdampak pada kinerja yang mengaktibatkan penurunan laba perusahaan. Untuk mengetahui bagaimana pengembangan karir di dalam hotel, perlu dilakukan penelitian awal. Hal ini dilakukan dengan menyebarkan kuisioner awal kepada 10 responden karyawan hotel. Dalam 
kuesioner pengembangan karir terdapat empat indikator yaitu: pendidikan $\left(\mathrm{X}_{1}\right)$, mutasi karyawan $\left(\mathrm{X}_{2}\right)$, Promosi $\left(\mathrm{X}_{3}\right)$, dan pengalaman kerja $\left(\mathrm{X}_{4}\right)$. Berikut merupakan tabel hasil kuisioner pengembangan karir. Hasil observasi awal variabel pengembangan karir menunjukkan bahwa pengembangan karir dikategorikan rendah, indikator pengalaman kerja dan pendidikan memiliki pengaruh yang paling besar dalam pengembangan karir. Pengembangan karir ini sangat dibutuhkan oleh karyawan sehingga karyawan dapat meningkatkan kinerjanya. Kinerja karyawan yang berkualitas tentunya ditentukan dari pengembangan karir seorang karyawan.

Selain pengembangan karir, rendahnya kinerja karyawan diduga disebabkan karena motivasi kerja. Motivasi kerja memiliki peranan yang penting untuk mendorong seorang karyawan agar lebih loyalitas terhadap perusahaan serta memiliki tanggung jawab yang penuh terhadap perusahaan. Peran manajer sangat dibutuhkan dalam memotivasi karyawannya. Menurut Suwatno \& Priansa (2011) menyatakan motivasi berasal dari kata latin moreve berarti dorongan, daya penggerak, atau kekuatan yang menyebabkan suatu tindakan atau perbuatan. Sementara itu, Rivai (2003) menunjukkan bahwa semakin kuat motivasi kerja, kinerja karyawan akan semakin tinggi. Motivasi akan meningkat apabila atasan memiliki interaksi yang baik dengan karyawannya, sehingga akan menyebabkan karyawan loyal terhadap perusahaan. Untuk mengetahui tingkat motivasi karyawan di dalam hotel perlu dilakukan penelitian awal. Hal ini dilakukan dengan menyebarkan kuisioner awal kepada 10 responden karyawan hotel. Dalam kuisioner tersebut terdapat tiga indikator di antaranya: kebutuhan untuk berprestasi $\left(X_{1}\right)$, kebutuhan berafiliasi $\left(\mathrm{X}_{2}\right)$, kebutuhan kekuatan $\left(\mathrm{X}_{3}\right)$. Berikut tabel hasil kuisioner awal motivasi kerja. Hasil observasi awal variabel motivasi kerja menunjukkan bahwa motivasi kerja masih dikategorikan rendah, indikator kebutuhan dalam mencapai kesuksesan memiliki pengaruh yang paling besar dalam motivasi kerja. Keinginan melakukan dan mengerjakan pekerjaan sebaikbaiknya agar mempunyai arti bagi diri sendiri, orang lain, maupun perusahaan yang merupakan peranan sangat penting dalam motivasi. Seorang karyawan yang diberikan motivasi yang besar maka karyawan itu diharapkan nantinya bekerja lebih giat dengan penuh loyalitas terhadap perusahaan, jika seorang karyawan dapat menyelesaikan pekerjaannya dengan baik tentunya ini merupakan keuntungan bagi perusahaan dan karyawan. Berdasarkan permasalahan pada latar belakang peneltian tersebut, maka penelitian memandang perlu untuk mengangkat judul “ pengaruh Pengembangan karir dan motivasi kerja terhadap kinerja karyawan pada Puri Lumbung Cottages Restaurant and Spa Munduk".

Dari pemaparan latar belakang diatas maka diperoleh rumusan masalah dalam bentuk pertanyaan (1) Apakah ada pengaruh $\mathrm{X}_{1}$ dan $\mathrm{X}_{2}$ terhadap $\mathrm{Y}$ pada Puri Lumbung Cottages Restaurant and Spa Munduk? (2) Apakah ada pengaruh $X_{1}$ terhadap $Y$ pada Puri Lumbung Cottages Restaurant and Spa Munduk? (3) Apakah ada pengaruh $\mathrm{X}_{2}$ terhadap $Y$ pada Puri Lumbung Cottages Restaurant and Spa Munduk? dan (4) Apakah ada pengaruh $X_{1}$ terhadap $\mathrm{X}_{2}$ pada Puri Lumbung Cottages Restaurant and Spa Munduk"?

Berdasarkan uraian rumusan masalah diatas maka tujuan penelitian yang ingin dicapai adalah (1) menguji pengaruh $X_{1}$ dan $X_{2}$ terhadap $Y$ pada Puri Lumbung Cottages Restaurant and Spa Munduk, (2) $X_{1}$ terhadap Y pada Puri Lumbung Cottages Restaurant and Spa Munduk, (3) $\mathrm{X}_{2}$ terhadap $\mathrm{Y}$ pada Puri Lumbung Cottages Restaurant and Spa Munduk dan (4) $\mathrm{X}_{1}$ terhadap $\mathrm{X}_{2}$ pada Puri Lumbung Cottages Restaurant and Spa Munduk. Hasil dari penelitian ini diharapkan memberikan manfaat, adapun manfaat penelitian ini sebagai berikut: (1) manfaat teoretis, peneliti mengharapkan agar hasil dari penelitian ini dapat memberikan manfaat bagi pengembangan ilmu penelitian dalam bidang Manajemen Sumber Daya Manusia kaitannya dengan variabel penelitian, (2) manfaat praktis, peneliti mengharapkan agar hasil penelitian ini dapat dipergunakan sebagai bahan pertimbangan perusahaan. 


\section{METODOLOGI}

Jenis penelitian yang digunakan adalah penelitian kuantitatif. Desain penelitian iniigunaka dalam penelitian ini adalahdesain penelitian kasual. Desain kasual ini dilakukan untuk mengkaji hubungan sebab akibat antara variabel yang mempengaruhi dan variabel yang dipengaruhi Sugiyono (2009; 56). Penelitian ini dilakukan untuk mengetahui pengaruh pengembangan karir dan motivasi kerja terhadap kinerja karyawan di Puri Lumbung Cottages Restaurant and Spa Munduk. Tahapan dalam desain penelitian kuantitatif kasual terdiri dari (1) Merumuskan Masalah, (2) Mengkaji Teori, (3) Merumuskan Hipotesis, (4) Mengumpulkan Data dan (6) Menarik Kesimpulan. Dalam mencari pengaruh pengembangan karir dan motivasi kerja terhadap kinerja karyawan di gunakan analisis jalur.

Subjek dalam penelitian ini adalah karyawan pada Puri Lumbung Cottages Restaurant and Spa Munduk. Sedangkan yang menjadi objek dalam penelitian adalah Pengembangan karir $\left(X_{1}\right)$, Motivasi kerja $\left(\mathrm{X}_{2}\right)$, dan Kinerja Karyawan $(\mathrm{Y})$. Sugiyono $(2009 ; 80)$ menyatakan bahwa, populasi adalah generalisasi yang terdiri atas obyek yang mempuanyai kualitas dan karateristik tertentu yang ditetapkan oleh penelitian untuk di pelajari dan kemudian ditarik kesimpulan. Populasi dalam penelitian ini adalah seluruh karyawan pada Puri Lumbung Cottages Restaurant and Spa munduk. Yang berjumlah 87 Orang. Penelitian ini dikategorikan sebagai penelitian populasi karena seluruh karyawan di jadikan sebagai obyek penelitian atau sasaran penelitian.

Adapun teknik pengambilan data yang digunakan dalam penelitian ini adalah wawancara dan kuesioner. Analisis data yang digunakan dalam penelitian ini yaitu analisis jalur (Path Analysis) adalah analisis yang digunakan untuk menganalisis pola hubungan yang tidak langsung. Analisis jalur merupakan suatu teknik untuk menganalisis hubungan sebab akibat yang terjadi pada regresi linier berganda jika variabel eksoden mempengaruhi variabel endogen tidak hanya secara langsung tetapi juga secara tidak langsung. Analisis ini digunakan untuk mengetahui besarnya pengaruh total dan pengaruh langsung serta tidak langsung dari variabel pengembgan karir dan motivasi kerja terhadap kinerja karyawan pada Puri Lumbung Cottages Restaurant and Spa. Mengingat data yang didapat dari hasil kuesioner untuk variabel pengembangan karir, dan motivasi adalah data ordinal sedangkan data yang dipakai untuk membuktikan kebenaran hipotesis harus data interval, maka data tersebut perlu diubah menjadi skala interval melalui "Method of Successive Interval (MSI)". Penelitian ini menggunakan pengolahan data dengan bantuan program SPSS 22.0 for windows. Sebelum dianalis dalam analisis jalur terlebih dahulu data harus diuji dengan uji validitas dan uji realibilitas.

\section{HASIL DAN PEMBAHASAN}

Berdasarkan hasil perhitungan uji statistik path analysis dengan menggunakan bantuan program Statistical Package for Social Science (SPSS) 22.0 For Windows maka diperoleh hasil perhitungan SPSS pada Tabel 2. 
JMPP, Vol. 4, No. 1, March 2021

p-ISSN: 2654-9719

\begin{tabular}{cccc} 
Parameter & $\begin{array}{c}\text { Tabel 2. Hasil Output Analisis Jalur } \\
\text { Nilai }\end{array}$ & $\begin{array}{c}P \text {-value } \\
\end{array}$ & $\alpha$ \\
\hline $\mathrm{Ryx}_{1} \mathrm{x}_{2}$ & 0,937 & 0,000 & 0,05 \\
\hline $\mathrm{R}^{2} \mathrm{yx}_{1} \mathrm{x}_{2}$ & 0,878 & - & 0,05 \\
\hline $\mathrm{Px}_{1} \mathrm{x}_{2}$ & 0,535 & 0,000 & 0,05 \\
\hline $\mathrm{P}^{2} \mathrm{x}_{1} \mathrm{x}_{2}$ & 0,286 & - & 0,05 \\
\hline $\mathrm{Pyx}_{1}$ & 0,310 & 0,007 & 0,04 \\
\hline $\mathrm{P}^{2} \mathrm{yx}_{1}$ & 0,096 & - & 0,04 \\
\hline $\mathrm{Pyx}_{2}$ & 0,901 & 0,000 & 0,05 \\
\hline $\mathrm{P}^{2} \mathrm{yx}_{2}$ & 0,811 & - & 0,05 \\
\hline $\mathrm{P}_{2} \varepsilon_{1}$ & 0,465 & - & - \\
\hline $\mathrm{Py}_{2}$ & 0,122 & - & - \\
\hline
\end{tabular}

Berdasarkan hasil analisis jalue pada Tabel 2. maka diperoleh struktur pengaruh variabel pengembangan karir dan motivasi kerja terhadap kinerja karyawan pada Puri Lumbung Cottages Restaurant and Spa Munduk tampak pada Gambar 1.

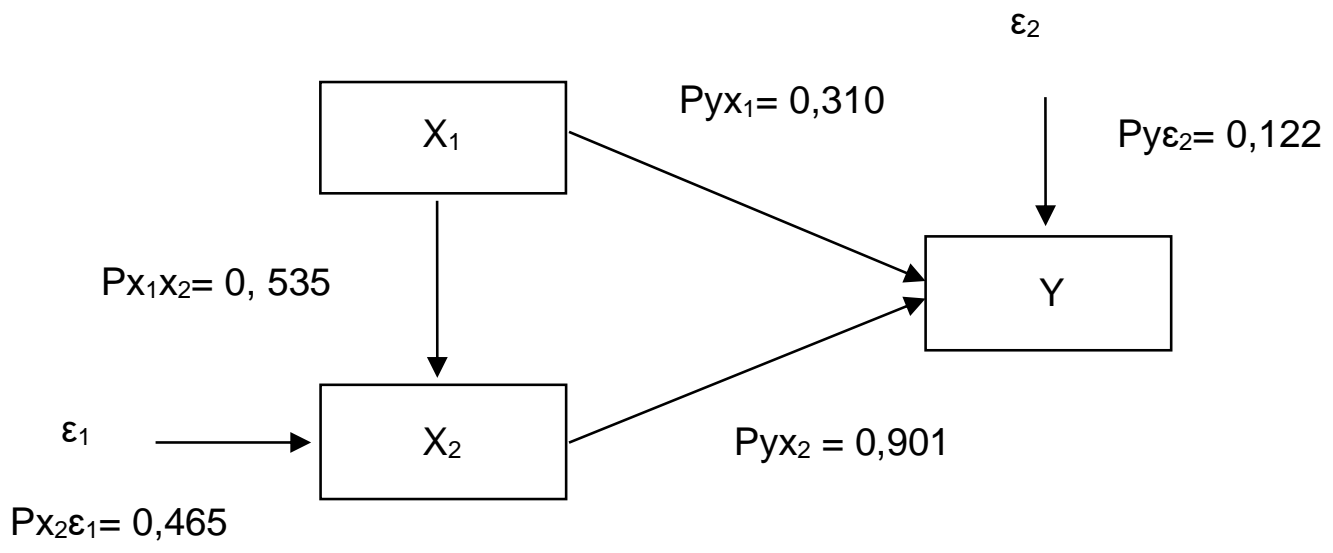

Gambar 1. Struktur pengaruh variabel X1, dan X2 terhadap Y.

Berdasarkan hasil perhitungan uji statistik analisis jalur dengan bantuan program SPSS 22.0 for windows, diperoleh hasil $\operatorname{Ryx}_{1} x_{2}=0,937$ dengan $p$-value $=0,000<$ alpha 0,05 sehingga keputusannya adalah menolak Ho. Ini artinya pengembangan karir $\left(X_{1}\right)$ dan motivasi kerja $\left(X_{2}\right)$ berpengaruh secara positif dan signifikan terhadap kinerja karyawan $(\mathrm{Y})$ pada Puri Lumbung Cottages Restaurant and Spa. Besar sumbangan pengaruh pengembangan karir $\left(X_{1}\right)$ dan motivasi kerja $\left(\mathrm{X}_{2}\right)$ kinerja karyawan $(\mathrm{Y})$ adalah 0,878 atau sebesar $87,8 \%$. Hasil penelitian menunjukkan bahwa variabel pengembangan karir $\left(\mathrm{X}_{1}\right)$ dan motivasi kerja $\left(\mathrm{X}_{2}\right)$ berpengaruh secara positif dan signifikan terhadap kinerja karyawan $(\mathrm{Y})$ melalui disiplin kerja $\left(\mathrm{X}_{2}\right)$ pada Puri Lumbung Cottages Restaurant and Spa. Hal ini sejalan dengan teori yang diungkapkan oleh Wibowo (2007) bahwa karyawan yang mempunyai kesempatan yang tinggi meningkatkan karirnya akan merangsang motivasinya untuk bekerja lebih baik. Pernyataan tersebut di dukung juga oleh Marwansyah (2009) yang menyatakan bahwa untuk mencapa tujuan perusahaan diperlukan dorongan kepada sumber daya manusia melalui perencanaan dan pengembangan 
karir karyawan selama mereka bekerja diperusahaan, sehingga mereka dapat terus termotivasi dan terus berusaha meningkatkan skill dan loyalitas terhadap perusahaan. Hasil penelitian ini mendukung penelitian yang dilakukan oleh Rosalina (2006) yang menyatakan bahwa pengembangan karir dan motivasi berpengaruh positif dan signifikan terhadap kinerja karyawan. Hasil penelitian ini dibuktikan dari penurunan penjualan hunian kamar yang berdampak pada kinerja karyawan. Hal tersebut disebabkan karena kurangnya pengembangan karir yang seharusnya mampu membantu karyawan dalam meningkatkan kinerja perusahaan dan motivasi kerja yang rendah disebabkan kurangnya perhatian perusahaan terhadap pemberian penghargaan, bonus dan apresiasi lainya kepada karyawan yang berkontribusi tinggi. Jika pihak perusahaan ingin meningkatkan kinerja karyawan maka perusahaan harus memperhatikan variabel pengembangan karir dan motivasi kerja. Pengaruh langsung pengembangan karir $\left(X_{1}\right)$ terhadap kinerja karyawan (Y) lebih kecil dibandingkan pengaruh tidak langsung yang melalui motivasi kerja $\left(\mathrm{X}_{2}\right)$. Hal tersebut dikarenakan pengembangan karir pada karyawan Puri Lumbung Cottages Restaurant and Spa belum memberikan kontribusi yang cukup dalam peningkatan kinerja dan laba perusahaan. Karyawan akan memberikan kontribusi yang besar apabila memiliki motivasi kerja dimana perusahaan memberikan penghargaan, apresiasi dan bonus lainnya sehingga karyawan terpacu untuk bekerja dengan lebih giat. Perusahaan harus memiliki strategi untuk meningkatkan kinerja di perusahaan, dengan cara memberikan motivasi kerja dalam berbagai bentuk yang bermanfaat bagi karyawan sehingga membantu perusahaan mencapai tujuan yang telah ditetapkan.

Berdasarkan hasil perhitungan uji statistik analisis jalur dengan bantuan program SPSS 22.0 for windows, diperoleh hasil $\mathrm{Pyx}_{1}=0,310$ dengan $p$-value $=0,004<$ alpha 0,05 sehingga keputusannya adalah menolak $\mathrm{Ho}$. Ini artinya pengembangan karir $\left(\mathrm{X}_{1}\right)$ berpengaruh secara positif dan signifikan terhadap kinerja karyawan $(\mathrm{Y})$ pada Puri Lumbung Cottages Restaurant and Spa. Pada Tabel 2 menunjukkan sumbangan pengaruh langsung pengembangan karir $\left(X_{1}\right)$ terhadap kinerja karyawan $(Y)$ yaitu 0,096 atau sebesar $9,6 \%$ sehingga besar sumbangan pengaruh pengembangan karir $\left(\mathrm{X}_{1}\right)$ terhadap kinerja karyawan $(\mathrm{Y})$ secara total yaitu 0,960 atau $96,0 \%$. Berdasarkan penelitian yang dilakukan, maka diperoleh temuan bahwa variabel pengembangan karir $\left(\mathrm{X}_{1}\right)$ berpengaruh positif dan signifikan terhadap kinerja karyawan $(\mathrm{Y})$ pada Puri Lumbung Cottages Restaurant and Spa. Hal ini sejalan dengan teori yang diungkapkan oleh Gorda $(2004 ; 149)$ pengembangan karir dalam suatu perusahaan akan semakin meningkatkan kepuasan karyawan, loyalitas dan kratifitas, kondisi yang demikian merupakan faktor pendorong peningkatan kinerja karyawan. Pengembangan karir di Puri Lumbung Cottages Restaurant and Spa belum diterapkan secara optimal. Perusahaan belum memiliki jenjang karir yang tersistem sehingga sering kali membuat karyawan bingung dalam hal pencapaian kerja seperti apa yang mampu meningkatkan karir dalam perusahaan. Pengembangan karir memiliki peranan penting dalam meningkatkan kinerja dan membantu karyawan dalam meningkatkan efektivitas pelaksanaan pekerjaan. Semakin baik karir seorang karyawan maka semakin tinggi pula kontribusi yang dilakukan. Oleh karena itu, perusahaan dituntut untuk memberikan pengembangan karir untuk memicu semangat dan meningkatkan kontribusi dalam bekerja karyawan.

Berdasarkan hasil perhitungan uji statistik analisis jalur dengan bantuan program SPSS 22.0 for windows, diperoleh hasil $\mathrm{Pyx}_{2}=0,901$ dengan $p$-value $=0,000<$ alpha 0,05 sehingga keputusannya adalah menolak Ho. Ini artinya motivasi kerja $\left(\mathrm{X}_{2}\right)$ berpengaruh secara positif dan signifikan terhadap kinerja karyawan ( $Y$ ) pada Puri Lumbung Cottages Restaurant and Spa. Pada Tabel 2 menunjukkan sumbangan pengaruh langsung motivasi kerja $\left(\mathrm{X}_{2}\right)$ terhadap kinerja karyawan (Y) yaitu 0,811 atau sebesar 81,1\%. Berdasarkan penelitian yang dilakukan, maka diperoleh temuan bahwa variabel motivasi kerja $\left(\mathrm{X}_{2}\right)$ berpengaruh secara positif dan signifikan terhadap kinerja karyawan (Y) pada Puri Lumbung Cottages Restaurant and Spa. Hal ini sejalan dengan teori yang diungkapkan (Saeed \& Asghar, 2012) bahwa motivasi memiliki arti yang begitu 
penting terhadap kinerja karyawan,di karenakan ketika karyawan termotivasi, kinerja karyawan akan meningkat, sebab karyawan memainkan peran penting dalam keberhasilan organisasi. Hal ini sejalan dengan hasil penelitian Amalia (2018) yang menyatakan motivasi kerja berpengaruh positif terhadap kinerja karyawan. Motivasi kerja sangat penting diperhatikan untuk meningkatkan produktivitas dalam bekerja. Hal tersebut akan mampu mendorong pihak perusahaan dalam mencapai tujuan perusahaan yang telah ditetapkan. Rendahnya motivasi kerja disebabkan karena pihak Puri Lumbung Cottages Restaurant and Spa jarang memberikan penghargaan, bonus dan apresiasi lainnya kepada karyawan yang berkontribusi besar. Oleh karena itu, pihak perusahaan hendaknya meningkatkan motivasi kerja melalui pemberian apresiasi kerja sehingga karyawan memiliki motivasi yang tinggi dalam melaksanakan pekerjaan.

Berdasarkan hasil perhitungan uji statistik analisis jalur dengan bantuan program SPSS 22.0 for windows, diperoleh hasil $\mathrm{Px}_{2} \mathrm{X}_{1}=0,535$ dengan $p$-value $=0,000<$ alpha 0,05 sehingga keputusannya adalah menolak Ho. Ini artinya pengembangan karir $\left(X_{1}\right)$ berpengaruh secara positif dan signifikan terhadap motivasi kerja $\left(\mathrm{X}_{2}\right)$ pada Puri Lumbung Cottages Restaurant and Spa. Besar sumbangan pengaruh pengembangan karir $\left(X_{1}\right)$ terhadap motivasi kerja $\left(X_{2}\right)$ adalah 0,286 atau sebesar $28,6 \%$. Hasil penelitian menunjukkan bahwa pengembangan karir $\left(X_{1}\right)$ berpengaruh secara positif dan signifikan terhadap terhadap motivasi kerja $\left(\mathrm{X}_{2}\right)$ pada Puri Lumbung Cottages Restaurant and Spa. Hal ini sejalan dengan teori yang diungkapkan Nawawi (2005) pengembangan karir adalah dorongan motivasi untuk maju dalam bekerja dilingkungan suatu perusahaan. Dengan adanya program pengembangan karir, dapat lebih meningkat dorongan atau motivasi kepada karyawan untuk lebih berprestasi dan memberikan kontribusi yang maksimal kepada perusahaan. Motivasi seseorang akan timbul apabila pengembangan karir yang ada disebuah perusahaan sudah ada dan jelas untuk dapat dilaksanakan mendapatkan hasil bahwa pengembangan karir berpengaruh signifikan terhadap motivasi kerja. Hasil penelitian ini mendukung penelitian yang dilakukan Rosalina (2006), yang menyatakan bahwa terdapat pengaruh yang positif dan signifikan dari pengembangan karir terhadap motivasi kerja. Pengembanngan karir dan motivasi kerja penting dalam peningkatan kinerja. Pengembangan karir yang tepat dan pemberian motivasi kerja berupa penghargaan, bonus dan apresiasi lainnya akan membantu perusahaan lebih cepat dalam mengembangkan dan meningkatkan laba perusahaan.

\section{SIMPULAN DAN SARAN}

Berdasarkan hasil yang dilakukan, maka dapat diatarik kesimpulan sebagai berikut. (1) Pengembangan karir dan motivasi kerja berpengaruh secara positif dan signifikan terhadap kinerja karyawan pada Puri Lumbung Cottages Restaurant and Spa. (2) Pengembangan karir berpengaruh secara positif dan signifikan terhadap kinerja karyawan pada Puri Lumbung Cottages Restaurant and Spa. (3) Motivasi kerja berpengaruh secara positif dan signifikan terhadap kinerja karyawan pada Puri Lumbung Cottages Restaurant and Spa. (4) Pengembangan karir berpengaruh secara positif dan signifikan terhadap motivasi kerja pada Puri Lumbung Cottages Restaurant and Spa.

Berdasarkan hasil penelitian dan pembahasan serta kesimpulan yang sudah dipaparkan, adapun saran yang diberikan melalui hasil penelitian sebagai berikut: (1) Bagi pihak manajemen Puri Lumbung Cottages Restaurant and Spa agar meningkatkan kinerja karyawan dengan memperhatikan pengembangan karir dan motivasi kerja. Pengembangan karir yang tepat dan pemberian motivasi kerja kepada karyawan sangat tergantung dengan kebijakan manajemen perusahaan dan sumber daya manusia yang dimiliki. Untuk meningkatkan hal tersebut pihak perusahaan perlu melakukan upaya evaluasi terhadap permasalahan internal. (2) Bagi peneliti selanjutnya, khususnya yang tertarik dan berminat untuk mendalami tentang pengembangan karir, motivasi kerja dan kinerja karyawan diharapkan untuk mengembangkan penelitian ini 
JMPP, Vol. 4, No. 1, March 2021

p-ISSN: 2654-9719

dengan menambahkan sampel yang lebih luas agar dapat menguji variabel lainnya yang diduga kuat dapat memengaruhi kinerja karyawan.

\section{Daftar Pustaka}

Amalia, N. M. R. (2018). Pengaruh lingkungan kerja dan motivasi kerja terhadap kinerja karyawan pegawai dinas tenaga kerja dan sosial kabupaten sleman. Pengaruh lingkungan kerya (Nurul R.A). Produktivitas. Bumi Aksara.

Gorda, I. G. N. (2004). Manajemen Sumber Daya Manusia. STIE Satya Darma.

Hasibuan, M. (2001). Manajemen Sumber Daya Manusia : pengertian dasar, pengertian, dan Masalah. PT. Toko Gunung Agung.

Martoyo, S. (2007). Manajemen Sumber Daya Manusia. BPFE-Yogjakarta.

Marwansyah. (2009). Manajemen sumber daya manusia. Alfabeta.

Nawawi. (2005). Manajemen sumber Daya Manusia Untuk Bisnis yang Kompetitif. Gajah mada University Press.

Rivai, V. (2003). Manajemen Sumber Daya Manusia untuk perusahaan. PT. Raja Grafindo Persada.

Rosalina, L. (2006). Pengaruh Pengembangan Karir dan Motivasi Terhadap Kinerja Karyawan Pada Verena Multi Finance Tbk Cabang Pekanbaru. Jurnal JOM FISIP, 3(2). https://jom.unri.ac.id/index.php/JOMFSIP/article/view/11241

Saeed, M. M., \& Asghar, M. A. (2012). Examining The Relationship Between Training, Motivation And Employess Job Performance-The Moderating Role Of Person Job Fit. Journal of Basic and Applied Scientific Research, 2(12). https://doi.org/12177-12183.

Soebagyo. (2012). Strategi Pengembangan Pariwisata Di Indonesia. LiQuidity, 1(2). https://doi.org/https://doi.org/10.32546/lq.v1i2.145

Sugiyono. (2009). Metode Penelitian Kuantitatif, Kualitatif dan R\&D. Alfabeta.

Suwatno, \& Priansa, D. (2011). Manajemen SDM Dalam Organisasi Publik dan Bisnis. Alfabeta. Wibowo. (2007). Manajemen Kinerja. Rajawali Pers. 